\title{
In Vitro Studies of Plasmid-mediated Penicillinase from Streptococcus faecalis Suggest a Staphylococcal Origin
}

\author{
Barbara E. Murray, Barbara Mederski-Samoraj, Steve K. Foster, James L. Brunton, and Paul Harford \\ Program in Infectious Diseases and Clinical Microbiology, University of Texas Medical School, Houston, Texas 77030; Department \\ of Medicine, Mount Sinai Hospital, and Department of Microbiology, University of Toronto Medical School, Toronto, Ontario, MSG 1 X5 \\ Canada
}

\begin{abstract}
A strain of Streptococcus faecalis with plasmid-mediated penicillinase production was studied further. Partially purified penicillinase from the $S$. faecalis strain hydrolyzed penicillin, ampicillin, and ureido-penicillins but not penicillinase-resistant semisynthetic penicillins, cephalosporins, or imipenem; hydrolysis was inhibited by clavulanic acid. Hydrolysis of a given antibiotic correlated with a marked increase in the minimal inhibitory concentration (MIC) of that drug when a high inoculum was used. As with most enterococci, the MICs of cephalosporins and penicillinase-resistant semisynthetic penicillins were too high for clinical usefulness, although these agents did not show an inoculum effect. Based upon hybridization under stringent conditions of plasmid DNA from the $S$. faecalis strain to cloned penicillinase genes from Staphylococcus aureus, it appears that these resistance determinants are highly homologous and suggests that this enzyme was introduced into streptococci from staphylococci.
\end{abstract}

\section{Introduction}

Despite the widespread use of penicillin since the 1940's, $\beta$ lactamase-mediated penicillin resistance was unknown among streptococci until 1983 when we reported a $\beta$-lactamase-producing clinical isolate of Streptococcus faecalis in this journal (1). We also demonstrated that the ability of this strain to hydrolyze penicillin was plasmid-mediated and transferrable. This observation is of importance not only for enterococci but for all streptococci since many R-plasmids found in $S$. faecalis are able to transfer to other streptococcal species (2). The current study was undertaken in order to $(a)$ investigate the substrate profile of the enterococcal $\beta$-lactamase, $(b)$ determine the effect of $\beta$ lactamase inhibitors, and $(c)$ seek genetic evidence that might indicate the origin of this resistance determinant.

\section{Methods}

Bacterial strains. S. faecalis strain $\mathrm{HH} 22$ was isolated from a urine specimen at Hermann Hospital, Houston, TX in 1981 and has been previously

This work was presented in part at the 24th Interscience Conference on Antimicrobiol Agents and Chemotherapy, Washington, DC, October 1984.

Address correspondence to Dr. Murray, Program in Infectious Diseases and Clinical Microbiology, University of Texas Medical School, Houston, TX 77030.

Received for publication 18 February 1985 and in revised form 4 September 1985

J. Clin. Invest.

(C) The American Society for Clinical Investigation, Inc.

0021-9738/86/01/0289/05 $\$ 1.00$

Volume 77, January 1986, 289-293 described (1). This strain is highly resistant (minimal inhibitory concentration $[\mathrm{MIC}]^{1}>2,000 \mu \mathrm{g} / \mathrm{ml}$ ) to gentamicin, is penicillin-resistant $\left(\mathrm{PEN}^{\mathrm{R}}\right)$ at high inocula, and produces $\beta$-lactamase $\left(\mathrm{Bla}^{+}\right)$. HH22-PEN ${ }^{S}$ is a novobiocin-treated derivative of $\mathrm{HH} 22$ which no longer produces penicillinase but is still $\mathrm{GM}^{\mathrm{R}}$. Other .tajor bacterial strains and plasmids used in this study are listed in Table I with their relevant properties. Staphylococcus aureus strain RN1753 containing pI524 was obtained from Richard Novick, The Public Health Research Institute of the City of NY (3), and the recombinant plasmid pJM13 was a gift from Jesse C. Rabinowitz (4), University of California, Berkeley, CA. Plasmids from gram-negative bacteria which were used in hybridizations include R6K(TEM-1), RP4(TEM-2), R57b(OXA-3), R16(OXA-2) (5) and pMG217(PSE-1) (supplied by G. A. Jacoby [6], Massachusetts General Hospital, Boston, MA).

Susceptibility testing. MICs were determined in brain-heart infusion broth by tube dilution as previously described (1); a final inoculum of $10^{3}$ colony forming units (CFU)/ml is referred to as a "low inoculum" and $10^{7} \mathrm{CFU} / \mathrm{ml}$ as a "high inoculum." Antibiotics used are shown in Tables II-IV; they and the $\beta$-lactamase inhibitors were obtained from their respective manufacturers or from Sigma Chemical Co., St. Louis, MO. The chromogenic cephalosporin nitrocefin was a gift from Glaxo Laboratories, Middlesex, England.

Enzyme preparation and hydrolysis studies. In order to obtain enzyme preparations for the hydrolysis assays, cultures of $\mathrm{HH} 22$ in brain-heart infusion broth were harvested by centrifugation. The supernatant was filter sterilized and then concentrated with a Diaflo Ultrafilter PM10 (Amicon Corp., Danvers, MA). The cellular pellet was resuspended in phosphate buffer $(\mathrm{PB})\left(0.1 \mathrm{M} \mathrm{NaPO}_{4}\right.$ buffer, $\left.\mathrm{pH} 7.0\right)$ with $0.02 \%$ sodium azide. This cellular suspension was sonicated extensively, centrifuged at $10,000 \mathrm{~g}$ for $20 \mathrm{~min}$ to remove cells, and then centrifuged sequentially at $30,000 \mathrm{~g}$ for $30 \mathrm{~min}$ and $110,000 \mathrm{~g}$ for $90 \mathrm{~min}$. The pellets (resuspended in PB) and supernatants were tested for enzyme activity with nitrocefin. The supernatant obtained after centrifugation at $110,000 \mathrm{~g}$ was applied to a BioGel A 0.5 column (Bio-Rad Laboratories, Richmond, CA) equilibrated with PB with $0.02 \%$ sodium azide and eluted with the same buffer. The active fractions were pooled and used for the hydrolysis assays.

Hydrolysis of penicillins was determined by a microiodometric assay (7) at $25^{\circ} \mathrm{C}$ using a substrate concentration of $0.2 \mathrm{mM}$. Hydrolysis of cephalosporins and imipenem was determined spectrophotometrically at $25^{\circ} \mathrm{C}$ with $0.1 \mathrm{mM}$ substrate by recording changes in absorbance at a wavelength that corresponded to the peak absorbance for each compound $(8,9)$. These peaks were determined before the addition of enzyme; all were in the $250-300 \mathrm{~nm}$ range. The effects of sulbactam and clavulanic acid were studied in two ways. In order to determine the effect on the MIC of penicillin, $10^{7} \mathrm{CFU} / \mathrm{ml}$ of $\mathrm{HH} 22$ were preincubated for $30 \mathrm{~min}$ with varying dilutions of the $\beta$-lactamase inhibitors before the addition of penicillin. The effect of inhibitors on the hydrolysis of nitrocefin was determined by preincubating $10^{6} \mathrm{CFU}$ of $\mathrm{HH} 22$ with various concentrations of inhibitor, then adding nitrocefin $(250 \mu \mathrm{g} / \mathrm{ml})$ in a final volume of $200 \mu \mathrm{l}$, and incubating at $25^{\circ} \mathrm{C}(8-10)$.

Plasmid isolation, DNA blotting, and hybridizations. Streptococcal

1. Abbreviations used in this paper: AMIK, amikacin; Bla, $\beta$-lactamase; bp, base pair; CA, clavulanic acid; CFU, colony-forming unit; EM, erythromycin; GM, gentamicin; KM, kanamycin; MIC, minimal inhibitory concentration; $\mathrm{PB}$, phosphate buffer; $\mathrm{PEN}$, penicillin; SB, sulbactam; SM, streptomycin; TC, tetracycline; TM, tobramycin. 
Table I. Strains and Plasmids Used in Hybridization and Cloning Experiments in This Study

\begin{tabular}{|c|c|c|}
\hline & Phenotype* & Reference/derivation \\
\hline \multicolumn{3}{|l|}{ S. faecalis strains } \\
\hline HH22 & $(\mathrm{GM}, \mathrm{TM}, \mathrm{KM}, \mathrm{AMIK}, \mathrm{SM})^{\mathrm{R}} \mathrm{PEN}^{\mathrm{R}}\left(\mathrm{Bla}^{+}\right) \mathrm{EM}^{\mathrm{R}} \mathrm{TC}^{\mathrm{R}}$ & 1 \\
\hline HH22-PEN ${ }^{S}$ & $(\mathrm{GM}, \mathrm{TM}, \mathrm{KM}, \mathrm{AMIK}, \mathrm{SM})^{\mathrm{R}} \mathrm{PEN}^{\mathrm{S}}\left(\mathrm{Bla}^{-}\right) \mathrm{EM}^{\mathrm{R}} \mathrm{TC}^{\mathrm{R}}$ & novobiocin-treated derivative of $\mathrm{HH} 22$ \\
\hline $\mathrm{XH} 22$ & $(\mathrm{GM}, \mathrm{TM}, \mathrm{KM}, \mathrm{AMIK},)^{\mathrm{R}} \operatorname{PEN}^{\mathrm{R}}\left(\mathrm{Bla}^{+}\right)$ & HH22 $\times$JH2-7 transconjugant $(1)$ \\
\hline XH22-(16) & $(\mathrm{GM}, \mathrm{TM}, \mathrm{KM}, \mathrm{AMIK}, \mathrm{SM})^{\mathrm{R}} \mathrm{EM}^{\mathrm{R}}$ & $\mathrm{HH} 22 \times \mathrm{JH} 2-7$ transconjugant \\
\hline XH22-(24) & $(\mathrm{KM}, \mathrm{AMIK}, \mathrm{SM})^{\mathrm{R}} \mathrm{EM}^{\mathrm{R}}$ & HH22 $\times$ JH2-7 transconjugant \\
\hline \multicolumn{3}{|l|}{ Plasmids } \\
\hline pI524 & $\left(\mathrm{Bla}^{+}, \mathrm{Pb}, \mathrm{Bi}, \mathrm{Cd}, \mathrm{Asa}, \mathrm{Asi}, \mathrm{Ant}, \mathrm{Hg}, \mathrm{Om}\right)$ & a staphylococcal plasmid which encodes $\operatorname{PEN}^{R}\left(\mathrm{Bla}^{+}\right)(22)$ \\
\hline pJM13 & $\operatorname{PEN}^{R}\left(\mathrm{Bla}^{+}\right) \mathrm{TC}^{\mathrm{R}}$ & $\begin{array}{l}\text { 4.6 MD Eco RI bla-specifying fragment of staphylococcal } \\
\text { plasmid pI } 258 \text { cloned into pMB9 (4) }\end{array}$ \\
\hline pMB9 & $\mathrm{TC}^{\mathrm{R}}$ & $\begin{array}{l}\text { an Escherichia coli cloning vector which does not encode } \\
\operatorname{PEN}^{\mathrm{R}} \text { or Bla (10) }\end{array}$ \\
\hline
\end{tabular}

$\mathrm{Pb}, \mathrm{Bi}, \mathrm{Cd}, \mathrm{Asa}, \mathrm{Asi}, \mathrm{Ant}, \mathrm{Hg}$, and Om indicate resistance to lead, bismuth, cadmium, arsenate, arsenite, antimony, mercury, and organomercurials respectively. For aminoglycosides, resistance is defined as an MIC $>2,000 \mu \mathrm{g} / \mathrm{ml}$.

and gram-negative plasmids were prepared by a modification of the method of LeBlanc and Lee (11) or as previously described (1). Staphylococci DNA was prepared in a similar fashion substituting lysostaphin $(20 \mu \mathrm{g} / \mathrm{ml})$ for lysozyme. Restriction endonuclease digestions were carried out according to the manufacturer's recommendations. Following electrophoresis in agarose gels, DNA was transferred to nitrocellulose (Schleicher and Schuell, Inc., Keene, NH) or Zeta-Probe filters (Bio-Rad Laboratories) by an adaptation of the method of Southern $(12,13)$.

Probe DNA included pI524 (31.8 kb), a 4.5-kb Sall fragment from pI524 encoding $\beta$-lactamase production and cloned into pMB9 (this study), and an 840-base pair (bp) Xbal/HindIII fragment of pJM13 previously shown to code for the leader peptide and $80 \%$ of the mature staphylococcal $\beta$-lactamase (4). Plasmid DNA from XH22 was also used to probe the gram-negative $\beta$-lactamase-producing strains. Nick translation was performed with ${ }^{32} \mathrm{P}$-labeled deoxycytidine triphosphate and cold nucleotides according to standard methods $(12,13) .{ }^{32} \mathrm{P}$-labeled probe DNA was hybridized to blotted DNA and to colony lysates under conditions of high stringency $\left(68^{\circ} \mathrm{C}\right.$ in $6 \times S S C$ or $42^{\circ} \mathrm{C}$ with $50 \%$ formamide $\left[12^{\circ} \mathrm{C}\right.$ below the melting temperature of duplex DNA, $\left.\left.\mathrm{T}_{\mathrm{m}}-12^{\circ} \mathrm{C}\right]\right)$ followed by high stringency washes (12).

\section{Results}

Enzyme and hydrolysis studies. No detectable hydrolysis of nitrocefin was produced by supernatant material from cultures at various phases of growth until this material was concentrated over 1,000-fold. Following sonication and removal of most intact cells, $\sim 50 \%$ of the $\beta$-lactamase activity sedimented in the 30,000 $g$ spin; $\sim 60 \%$ of the remaining supernatant activity was sedimented by centrifugation at $110,000 \mathrm{~g}$. Less extensive sonication resulted in more activity being sedimented in the first spin. Passage of the $110,000 \mathrm{~g}$ supernatant material over the BioGel A 0.5 column resulted in elution of $\beta$-lactamase activity in the void volume, indicating an apparent molecular weight of $>500,000$. Activity of pre- and postchromatographed material was also retained by Diaflo ultrafilter XM100A (Amicon Corp.) confirming a molecular weight of at least 100,000.

The chromatographed material was used to determine the rates of hydrolysis of various substrates (Table II). Penicillin, ampicillin, and the ureido penicillins were most rapidly hydrolyzed, followed by ticarcillin and carbenicillin; there was little or no hydrolysis of methicillin, nafcillin, the cephalosporin-like compounds, or imipenen. This pattern is typical of a penicillin- ase, such as that of $S$. aureus. The agents which were most rapidly hydrolyzed were also those which had the least efficacy against intact organisms. Table III shows the effect of high and low inocula on the susceptibility of $\mathrm{HH} 22$ to the various $\beta$-lactam agents. As previously reported, this organism is highly resistant to penicillin with an inoculum of $10^{7} \mathrm{CFU} / \mathrm{ml}$ but is inhibited by $2 \mathrm{U} / \mathrm{ml}$ with $10^{3} \mathrm{CFU} / \mathrm{ml}$. The same marked effect of the high inoculum was seen with ampicillin, piperacillin, and mezlocillin, but little or no change was observed with the penicillinase-resistant penicillins, the cephalosporin-like compounds, or imipenem. The susceptibility to ticarcillin was moderately affected (eightfold) by the high inoculum.

The effects of $\beta$-lactamase inhibitors on the enterococcal $\beta$ lactamase are shown in Table IV. When clavulanic acid (CA) was tested with penicillin, the MIC of penicillin was $2 \mathrm{U} / \mathrm{ml}$ (with $50 \mu \mathrm{g} / \mathrm{ml}$ of CA), $4 \mathrm{U} / \mathrm{ml}$ (with $25,10,4,2$, and $1 \mu \mathrm{g} / \mathrm{ml}$ of CA), $256 \mathrm{U} / \mathrm{ml}$ (with $0.5 \mu \mathrm{g} / \mathrm{ml}$ of CA), and $>1,000 \mathrm{U} / \mathrm{ml}$

Table II. Relative Hydrolysis of $\beta$-Lactams by Partially Purified Enterococcal $\beta$-Lactamase

\begin{tabular}{lc}
\hline Antibiotics & Percent hydrolysis* \\
\hline Penicillin & 100 \\
Ampicillin & 157 \\
Methicillin & 3 \\
Nafcillin & $<1$ \\
Ticarcillin & 29 \\
Carbenicillin & 44 \\
Piperacillin & 175 \\
Mezlocillin & 200 \\
Cephalothin & $<1$ \\
Cefazolin & $<1$ \\
Cefoperazone & $<1$ \\
Cephaloridine & $<1$ \\
Cefotaxime & $<1$ \\
Moxalactam & $<1$ \\
Imipenem & $<1$ \\
&
\end{tabular}

* Relative to the rate of hydrolysis of penicillin G. 
Table III. Effect of Inoculum on the Susceptibility of Enterococcal Strain HH22 to $\beta$-Lactam Antibiotics

\begin{tabular}{lrr}
\hline MIC $(\mu g / m l)$ & \multicolumn{2}{c}{ Inoculum $($ CFU/ml) } \\
\cline { 2 - 3 } Antibiotic & $10^{3}$ & $10^{7}$ \\
\hline Penicillin G & $2^{*}$ & 1000 \\
Ampicillin & 2 & $>1000$ \\
Methicillin & 32 & 32 \\
Nafcillin & 8 & 8 \\
Ticarcillin & 64 & 500 \\
Piperacillin & 2 & 1000 \\
Mezlocillin & 1 & $>1000$ \\
Cephalothin & 32 & 64 \\
Cefoperazone & 16 & 16 \\
Moxalactam & 500 & 500 \\
Imipenem & $\leq 1$ & $\leq 1$ \\
\end{tabular}

* MIC of penicillin is expressed in units per milliliters.

(with $0.25 \mu \mathrm{g} / \mathrm{ml}$ or less). In the microtiter assay with nitrocefin, CA inhibited hydrolysis at $1.0 \mu \mathrm{g} / \mathrm{ml}$ but not $0.5 \mu \mathrm{g} / \mathrm{ml}$ following $4 \mathrm{~h}$ of incubation; at $18 \mathrm{~h}$, there was also hydrolysis with 1.0, 2.0 , and $4.0 \mu \mathrm{g} / \mathrm{ml}$ of CA but not with higher concentrations. With sulbactam (SB), the MIC of penicillin was $4 \mathrm{U} / \mathrm{ml}$ with 50 $\mu \mathrm{g} / \mathrm{ml} \mathrm{SB}, 16 \mathrm{U} / \mathrm{ml}$ with $25 \mu \mathrm{g} / \mathrm{ml} \mathrm{SB}, 32$ with $8 \mu \mathrm{g} / \mathrm{ml} \mathrm{SB}$, and $1,000 \mathrm{U} / \mathrm{ml}$ with $2 \mu \mathrm{g} / \mathrm{ml}$ or less (Table IV). In the hydrolysis inhibition assay, $50 \mu \mathrm{g} / \mathrm{ml}$ of SB inhibited visible evidence of hydrolysis at $4 \mathrm{~h}$, with very slight hydrolysis with $25 \mu \mathrm{g} / \mathrm{ml}$; at $18 \mathrm{~h}$, hydrolysis had occurred even in $100 \mu \mathrm{g} / \mathrm{ml}$ of SB.

Hybridizations. Initial studies showed hybridization of the staphylococcal plasmid pI524 to an $82 \mathrm{~kb}$ (54 megadalton [MD]) plasmid from $\mathrm{HH} 22$ and its transconjugant $\mathrm{XH}-22$, and to 21.8$\mathrm{kb}$ (14.4 MD) and 5.1-kb (3.4 MD) EcoRI digestion fragments of plasmid DNA from the same strains (not shown). The 4.5kb SalI fragment of pI524 which carries the $\beta$-lactamase gene was cloned into pMB9 (which has no $\beta$-lactamase gene) and then used as a crude probe for $\beta$-lactamase sequences in the enterococcal plasmids. Fig. 1 shows that labeled probe hybridized with the 54-MD ( $82 \mathrm{~kb}$ ) plasmid in $\mathrm{HH}-22$ and its $\beta$-lactamaseproducing $\left(\mathrm{Bla}^{+}\right)$transconjugant $\mathrm{XH} 22$. There was no hybridization to plasmids from $\mathrm{Bla}^{-}$derivatives (XH22-(24) [shown in Fig. 1], XH22-(16), or HH22-PEN $\mathrm{H}^{\mathrm{S}}\left(\mathrm{Bla}^{-}\right)$[not shown]). This smaller probe hybridized only to a $5.1-\mathrm{kb}(3.4 \mathrm{MD})$ fragment in EcoRI digests of plasmid DNA isolated from $\mathrm{Bla}^{+}$strains; again, there was no hybridization demonstrated with digested DNA isolated from $\mathrm{Bla}^{-}$strains (data not shown).

To ensure that the above results represented hybridization due to $\beta$-lactamase gene sequences, hybridization was performed using the 840-bp XbaI/HindIII fragment of pJM13 known to be located within the $\beta$-lactamase gene of the staphylococcal plasmid pI258 (4). Fig. 2 shows that this probe hybridized only to a 5.1-kb EcoRI fragment of $\mathrm{HH} 22$ while there was no hybridization to $\mathrm{HH} 22-\mathrm{PEN}^{\mathrm{S}}\left(\mathrm{Bla}^{-}\right)$. This fragment appears to be part of a doublet or triplet of similarly sized fragments (better seen in other gels). Neither this probe nor labeled XH22 hybridized to DNA from the gram-negative strains that produced TEM, OXA, or PSE type $\beta$-lactamases.

\section{Discussion}

Although enterococci are intrinsically more resistant to penicillins than other streptococci (14), $\beta$-lactamase production is a new mechanism of resistance for these organisms and in fact is new for the genus Streptococcus. In our initial report, we observed that enterococcal strain $\mathrm{HH} 22$ was resistant to high levels of penicillin using a heavy inoculum and that penicillin activity was rapidly destroyed in cultures in which this organism was growing (1). We have now shown that this $\beta$-lactamase acts like a typical penicillinase, such as produced by staphylococci $(15$, 16), since it hydrolyzes penicillin, ampicillin, ureido penicillins, and to a lesser extent, carboxy penicillins, but does not hydrolyze penicillinase-resistant penicillins such as methicillin, the cephalosporins, or imipenem (17-19). The hydrolysis results correlate with marked increases in resistance to these compounds when heavy inocula are used. Unfortunately, the $\beta$-lactams that resist hydrolysis are in general those, such as the cephalosporins and methicillin, which have little intrinsic activity or clinical usefulness against enterococci (14). They should be useful if this plasmid-mediated resistance determinant moves into other

Table IV. Effect of $\beta$-Lactamase Inhibitors on Penicillin Susceptibility of HH22

\begin{tabular}{|c|c|c|c|c|c|c|c|c|c|c|}
\hline & \multicolumn{10}{|c|}{ Concentration of inhibitor } \\
\hline & 0 & 0.25 & 0.5 & 1 & 2 & 4 & 10 & 25 & 50 & 100 \\
\hline \multicolumn{11}{|l|}{$\mathrm{CA}(\mu g / m l)$} \\
\hline MIC of penicillin $(U / m l)^{*}$ & 1,000 & 1,000 & 256 & 4 & 4 & 4 & 4 & 4 & 2 & 2 \\
\hline \multicolumn{11}{|l|}{ Hydrolysis $\ddagger$} \\
\hline $4 \mathrm{~h}$ & + & + & + & - & - & - & - & - & - & - \\
\hline $18 \mathrm{~h}$ & + & + & + & + & + & \pm & - & - & - & - \\
\hline \multicolumn{11}{|l|}{$\mathrm{SB}(\mu g / m l)$} \\
\hline MIC of penicillin $(U / m l)^{*}$ & 1,000 & 1,000 & 1,000 & 1,000 & 1,000 & 32 & 32 & 16 & 4 & 4 \\
\hline \multicolumn{11}{|l|}{ Hydrolysis $\ddagger$} \\
\hline $4 \mathrm{~h}$ & + & + & + & + & + & + & + & \pm & - & - \\
\hline $18 \mathrm{~h}$ & + & + & + & + & + & + & + & + & + & + \\
\hline
\end{tabular}

* With an inoculum of $10^{7} \mathrm{CFU} / \mathrm{ml}$ of HH22. $\ddagger$ Hydrolysis of nitrocefin by $\mathrm{HH} 22$ (see text). 


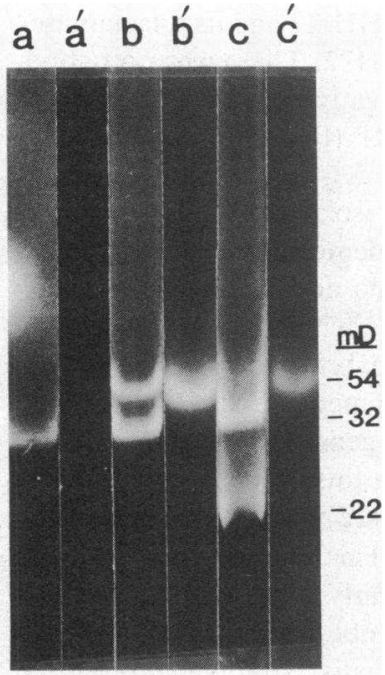

Figure 1. Agarose gel electrophoresis of plasmid DNA from $(a)$ a $\mathrm{PEN}^{\mathrm{S}}\left(\mathrm{Bla}^{-}\right)$transconjugant, XH22-(24) (KM, AMIK, SM) ${ }^{R} \mathbf{E M}^{\mathrm{R}}$ (Table I), $(b)$ a PEN ${ }^{\mathrm{R}}$ transconjugant, XH22 (GM, TM, $\mathrm{KM}, \mathrm{AMIK})^{\mathrm{R}} \mathrm{PEN}^{\mathrm{R}}\left(\mathrm{Bla}^{+}\right),(c)$ the original clinical isolate $\mathrm{HH} 22$ (GM, TM, KM, AMIK SM) ${ }^{R} \operatorname{PEN}^{R}\left(B^{+}\right) E^{R} M^{R}$, and the corresponding autoradiograph $\left(a^{\prime}, b^{\prime}, c^{\prime}\right)$ following hybridization to $a^{32} \mathrm{P}$-labeled Sal I $\mathrm{Bla}^{+}$fragment of the staphylococcal plasmid pI524. Approximate sizes of the plasmids of $\mathrm{HH} 22$ are given as megadaltons (MD).

streptococci, but they are not likely to have a therapeutic role for enterococcal infections. Imipenem, which shows promise as an effective anti-enterococcal agent in other studies $(17,20)$, was the only $\beta$-lactam intrinsically active as well as resistant to hydrolysis by this enzyme. Vancomycin inhibited this strain (data not shown) as did the combination of CA with penicillin; SB was not as potent as CA, which is again similar to its effect on staphylococcal $\beta$-lactamase (21).
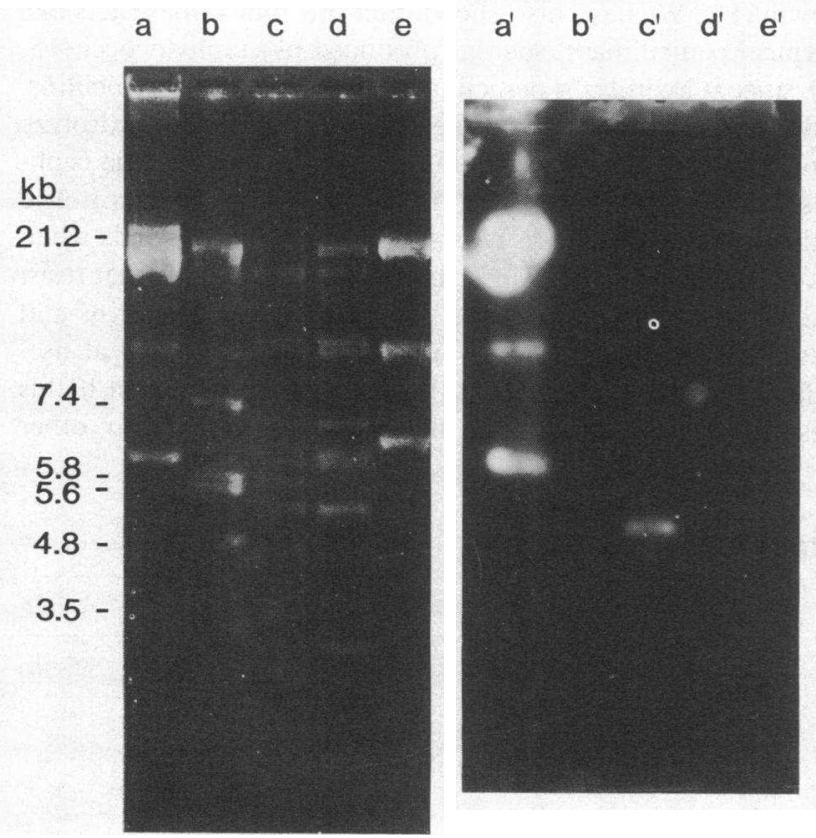

Figure 2. On the left, agarose gel electrophoresis of DNA from (a) pJM13 (partially digested), (b) lambda digested with EcoRI, (c) HH22, digested with EcoRI, (d) the novobiocin-generated derivative, HH22$\operatorname{PEN}^{\mathrm{S}}\left(\mathrm{Bla}^{-}\right)$, digested with $E c o \mathrm{RI}$, and $(e)$ lambda digested with HindIII. On the right is the autoradiograph of this DNA following hybridization to an 840-bp ${ }^{32} \mathrm{P}$-labeled $\mathrm{Xba \textrm {I } / H i n d I I I}$ fragment of $\mathrm{pJM} 13$ which encodes most of the staphylococcal bla gene (4). The sizes on the left are derived from lambda digested with EcoRI (lane b) in kilobases $(\mathbf{k b})$.
The similarity of the substrate profile of the enterococcal $\beta$ lactamase to that reported for staphylococcal $\beta$-lactamases suggested that their gene sequences might be related and that the enterococcal bla gene may be derived from the staphylococcal gene pool. Initial hybridizations using pI524 and its 4.5-kb SalI $\beta$-lactamase-specifying fragment suggested that the enterococcal gene was carried on the 82-kb plasmid and was highly homologous to the staphylococcal gene. However, there was concern that the homology demonstrated might be due to non- $\beta$-lactamase sequences carried on the pI524 fragment. The 840-bp HindIII/XbaI fragment of pJM13 carries only 75 bp upstream of the bla promoter in addition to the promoter, leader sequence, and $80 \%$ of the $\beta$-lactamase structural gene (4). Thus, it is an extremely specific probe and its hybridization, under stringent conditions, to a 5.1-kb EcoRI fragment in digests of plasmid DNA isolated from $\mathrm{HH} 22$ and $\beta$-lactamase-producing transconjugants but not to the novobiocin "cured" derivative $\mathrm{HH} 22-\mathrm{PEN}^{\mathrm{S}}\left(\mathrm{Bla}^{-}\right)$suggests that the $\beta$-lactamase gene of $\mathrm{HH} 22$ is highly related to that found in $S$. aureus. Other hybridizations using the entire $31.8-\mathrm{kb}$ plasmid pI524 as a probe showed homology with only one additional fragment, which suggests that, with the exception of the penicillinase determinants, the plasmids are largely unrelated. Furthermore, attempts to transfer the plasmid to $S$. aureus have failed (unpublished observations). A number of other antibiotic resistance determinants and transposons in the two genera have been found to be homologous (22); moreover, transfer of certain macrolide-lincosamide-streptogramin resistance plasmids from streptococci to staphylococci and vice versa has been demonstrated (23). With respect to the $\beta$-lactamase gene, Shalita et al. (24) have suggested on the basis of the genetic data reported by Ashehov (25) that the bla gene and a flanking invertible sequence may constitute a transposable unit. A similar organization of the bla gene in HH-22 would strengthen the suggestion that it was introduced from $S$. aureus.

It is interesting that the enterococcal $\beta$-lactamase appears to be completely cell bound with a molecular weight of over 500,000 . Most $\beta$-lactamase producing $S$. aureus strains secrete their $\beta$-lactamase as an exoenzyme of $\sim 29,000$. A few strains, however, secrete $<10 \%$ of the enzyme that they produce (26). Nielsen and Lampen (27) showed that $S$. aureus 8325-4 containing pI524 secreted two-thirds and retained one-third of the total $\beta$-lactamase as a membrane-bound form (27). The membrane-bound form differed from the exoenzyme in retaining part of the leader sequence which also carried a lipophilic modification $(27,28)$. The bla gene of the staphylococcal plasmid pI 258 has also been shown to produce a completely membrane-bound product in Bacillus subtilis (28). Thus, the proportion of $\beta$-lactamase that is processed to form membrane-bound lipoprotein may be dependent on the host cells. Efforts to solubilize the streptococcal enzyme and determine the basis of its cell binding are in progress.

In summary, the activity of the streptococcal $\beta$-lactamase is similar to that of a typical penicillinase. Specific hybridization to staphylococcal $\beta$-lactamase gene probes suggests that the penicillinase determinant may have spread from $S$. aureus to streptococci. One could speculate that the difference in the cellular binding of these two enzymes is due to genetic divergence leading to closely related but different proteins or to different processing of identical genes by the different host strains. Further studies will be required to determine which if either of these hypotheses is correct. 


\section{Acknowledgments}

We especially thank $\mathbf{J}$. Rabinowitz for the important contribution of pJM13 and D. LeBlanc and L. Lee for the many conversations and helpful suggestions regarding plasmid purification.

This work was supported in part by the National Institutes of Health grant AI-19011 to Dr. Murray, by the Medical Research Council of Canada grant MA7288 to Dr. Brunton, and by a fellowship from the Ontario Ministry of Health to Barbara Mederski-Samoraj.

\section{References}

1. Murray, B. E., and B. Mederski-Samaroj. 1983. Transferable $\beta$ lactamase: A new mechanism for in vitro penicillin resistance in Streptococcus faecalis. J. Clin. Invest. 72:1168-1171.

2. Clewell, D. B. 1981. Plasmids, drug resistance, and gene transfer in the genus Streptococcus. Microbiol. Rev. 45:409-436.

3. Murphy, E., and R. P. Novick. 1979. Physical mapping of Staphylococcus aureus penicillinase plasmid pI524: characterization of an invertible region. Mol. Gen. Genet. 175:19-30.

4. McLaughlin, J. R., C. L. Murray, and J. C. Rabinowitz. 1981. Unique features of the ribosomal binding site sequence of the grampositive Staphylococcus aureus $\beta$-lactamase gene. J. Biol. Chem. 256: 11283-11291.

5. Mathews, M., and R. W. Hedges. 1976. Analytical isoelectric focusing of $\mathbf{R}$ factor-determined $\beta$-lactamase: correlation with plasmid compatibility. J. Bacteriol. 125:713-718.

6. Medeiros, A. A., R. W. Hedges, and G. A. Jacoby. 1982. Spread of a "Pseudomonas-specific" $\beta$-lactamase to plasmids of enterobacteria. J. Bacteriol. 149:700-707.

7. Sykes, R. B., and K. Nordstrom. 1972. Microiodometric determination of $\beta$-lactamase activity. Antimicrob. Agents Chemother. 1:9499.

8. O'Callaghan, C. H., P. W. Muggleton, and G. W. Ross. 1969. Effects of $\beta$-lactamase from gram-negative organisms on cephalosporins and penicillins. Antimicrob. Agents Chemother.-1968 G. Hobby, editor. American Society for Microbiology, Bethesda, MD. 57-63.

9. Lucas, T. J. 1979. An evaluation of 12 methods for demonstration of penicillinase. J. Clin. Pathol. 12:1061-1065.

10. O'Callaghan, C. H., A. Morris, S. M. Kirby, and A. H. Shingler. 1972. Novel method for detection of $\beta$-lactamases by using a chromogenic cephalosporin substrate. Antimicrob. Agents Chemother. 1:283-288.

11. LeBlanc, D. J., and L. Lee. 1982. Characterization of two tetracycline resistance determinants in Streptococcus faecalis JH1. J. Bacteriol. 150:835-843.

12. Maniatis, T., E. F. Fritsch, and J. Sambrook, editors. 1982. Molecular Cloning. Cold Spring Harbor Laboratory, Cold Spring Harbor, NY.
13. Rudy, R. P., and B. E. Murray. 1984. Evidence for an epidemic trimethoprim resistance plasmid in fecal isolates of $E$. coli from citizens of the United States studying in Mexico. J. Infect. Dis. 150:25-29.

14. Toala, P., A. McDonald, C. Wilcox, and M. Finland. 1969. Susceptibility of group D streptococcus (Enterococcus) to 21 antibiotics in vitro. Am. J. Med. Sci. 258:416-430.

15. Citri, N., and M. R. Pollock. 1966. The biochemistry and function of $\beta$-lactamase (penicillinase). Adv. Enzymol. 28:237-243.

16. Richmond, M. H. 1963. Purification and properties of the exopenicillinase from Staphylococcus aureus. Biochem. J. 88:452-453.

17. Neu, H. C., and P. Labthavikul. 1982. Comparative in vitro activity of $\mathrm{N}$-formimidoyl thienamycin against gram-positive and gramnegative aerobic and anaerobic species and its $\beta$-lactamase stability. $A n$ timicrob. Agents Chemother. 21:180-187.

18. Fu, K. P., and H. C. Neu. 1978. Azlocillin and mezlocillin: new ureido penicillins. Antimicrob. Agents Chemother. 13:930-938.

19. Barry, A. L., C. Thornsberry, R. N. Jones, and T. L. Gavan. In vitro activity of mezlocillin and azlocillin compared with that of four other penicillins and two aminoglycosides. Cleve. Clin. Q. 47:311-319.

20. Eliopoulos, G. M., and R. C. Moellering. 1981. Susceptibility of enterococci and Listeria monocytogenes to $\mathrm{N}$-formimidoyl thienamycin alone and in combination with an aminoglycoside. Antimicrob. Agents Chemother. 19:789-793.

21. English, A. R., J. A. Retsema, A. E. Girand, J. E. Lynch, and W. E. Barth. 1978. CP-45,899, a beta-lactamase inhibitor that extends the antibacterial spectrum of beta-lactams; initial bacteriological characterization. Antimicrob. Agents Chemoter. 14:414-419.

22. Brunton, J. 1984. Antibiotic resistance plasmids of streptococci, staphylococci and bacteroides. In Antimicrobial Drug Resistance. L. E. Bryan, editor. Academic Press, Orlando, FL. 530-561.

23. Shaberg, D. R., D. B. Clewell, and L. Glatzer. 1982. Conjugative transfer of R-plasmids from Streptococcus faecalis to Staphylococcus aureus. Antimicrob. Agents Chemother. 22:204-207.

24. Shalita, Z., E. Murphy, and R. P. Novick. 1980. Penicillinase plasmids of Staphylococcus aureus: structural and evolutionary relationships. Plasmid. 3:291-311.

25. Ashehov, E. H. 1969. The genetics of penicillinase production in Staphylococcus aureus strain PS80. J. Gen. Microbiol. 49:289-301.

26. Dyke, K. G. H. 1979. $\beta$-lactamases of Staphylococcus aureus. In $\beta$-lactamases. J. M. T. Hamilton Miller, and J. T. Smith. Academic Press, New York. 291-310.

27. Nielsen, J. B. K., and J. O. Lampen. 1982. Membrane-bound penicillinases in gram-positive bacteria. J. Biol. Chem. 257:4490-4495.

28. Saunders, C. W., B. J. Schmidt, M. S. Mirot, L. D. Thompson, and M. S. Guyer. 1984. Use of chromosomal integration in the establishment and expression of blaZ, a Staphylococcus aureus $\beta$-lactamase gene in Bacillus subtilis. J. Bacteriol. 157:718-726. 